\title{
Modulated vasodilator responses to natriuretic peptides in rats exposed to chronic hypoxia
}

\author{
Y. Mitani*, J. Maruyama ${ }^{+}$, A. Yokochi ${ }^{\#}$, K. Maruyama $^{\#}$, T. Yoshimoto ${ }^{\star}$, M. Naruse ${ }^{\ddagger}$, M. Sakurai*
}

Modulated vasodilator responses to natriuretic peptides in rats exposed to chronic hypoxia. Y. Mitani, J. Maruyama, A. Yokochi, K. Maruyama, T. Yoshimoto, M. Naruse, M. Sakurai. (C) ERS Journals Ltd 2000

ABSTRACT: Natriuretic peptides (NPs), such as atrial natriuretic peptide (ANP), Ctype natriuretic peptide (CNP), and adrenomedullin (ADM), are endogenous vasodilators acting via specific receptors. This study addressed the question of how pulmonary artery (PA) responses to these peptides and the gene expression of their receptors are modulated in pulmonary hypertension rat models exposed to chronic hypoxia.

In this study, isometric tension was measured in PA rings exposed to these NPs and 8-bromoguanosine $3^{\prime}, 5^{\prime}$ - cyclic monophosphate (8-bromo-cGMP). It was compared with messenger ribonucleic acid (mRNA) levels of NP-A and -B receptors, which bind to ANP and CNP, respectively, as determined by ribonuclease (RNase) protection assay.

Chronic hypoxia increased the maximal relaxation elicited by ANP, but the responses to CNP and 8-bromo-cGMP were unchanged. Chronic hypoxia did not change NP-A and $-B$ receptor mRNA levels.

The results showed that pulmonary artery response to atrial natriuretic peptide is selectively enhanced, possibly via a post-transcriptional modulation of its receptor in chronically hypoxia rats. These pharmacological characteristics of atrial natriuretic peptide are consistent with the hypothesis that the atrial natriuretic peptide system is protective against the progression of pulmonary hypertension.

Eur Respir J 2000; 15: 400-406.

Pulmonary arteries in rats with pulmonary hypertension $(\mathrm{PH})$, elicited by chronic hypoxia or injection of monocrotaline, differ structurally and functionally from normal vessels $[1,2]$. Medial thickening observed in these vessels is associated with the hypertrophy and hyperplasia of vascular smooth muscle cells (VSMCs) and increased extracellular matrix protein $[1,2]$. The vasorelaxant responses of these vessels are modulated, depending on the mechanism of action of the vasodilators. This study and other previous studies have demonstrated that the vasorelaxant responses to acetylcholine, sodium nitroprusside and isoproterenol were impaired in animal models of $\mathrm{PH}$ while those responses to $\mathrm{Ca}^{2+}$ channel blockers and $\mathrm{K}^{+}$channel openers were augmented [3-6]. The alteration of pulmonary vasomotor function may be important in aggravating or mitigating the development of $\mathrm{PH}$.

Atrial natriuretic peptide (ANP) is a member of natriuretic peptide (NP) family which consists of at least four vasodilating peptides, including brain natriuretic peptide (BNP), C- type natriuretic peptide (CNP), and adrenomedullin (ADM), all of which act via specific receptors. ANP and BNP are circulating hormones released from the heart, acting via an NP-A receptor with a particulate guanylate cyclase-A activity, while CNP is an endothelium-derived relaxing factor mediated by a NP-B receptor with a particulate guanylate cyclase-B activity [7-9]. In contrast, ADM, via specific receptors, acts mainly through adenosine
Depts of *Paediatrics, ${ }^{+}$Physiology and \#Anesthesiology, Mie University School of Medicine, Tsu, Mie, Japan. "Dept of Medicine, Institute of Clinical Endocrinology, Tokyo Women's Medical College, Shinjuku-ku, Tokyo, Japan.

Correspondence: K. Maruyama

Dept of Anesthesiology

Mie University School of Medicine

2-174 Edobashi,

Tsu City, Mie Pref 514

Japan

Fax: 81592315229

Keywords: Atrial natriuretic peptide pulmonary hypertension

rat

smooth muscle

Received: April 271999

Accepted after revision October 201999 $3^{\prime}, 5^{\prime}$-cyclic monophosphate (cAMP) in the VSMCs, but in part via releasing NO from endothelium $[10,11]$. The manner in which chronic hypoxia modulates the vasorelaxant responses to these new NPs and the gene expression of specific receptors in rats is unknown. This question is of pathophysiological importance, because the function and gene expression of NP receptor subtypes is switched in phenotypically modulated VSMCs, as well as in various pathological conditions. NP-A receptor is the predominant subtype in intact rat aorta, representing the contractile phenotype of smooth muscle cells, whereas the NP-B receptor is predominant in cultured aortic smooth muscle cells with the synthetic phenotype [12]. The phenotyperelated switching of the receptor subtypes for NPs is also confirmed in vivo, gene expression of NP-B receptor was increased with an enhanced guanosine $3^{\prime}, 5^{\prime}$-cyclic monophosphate (cGMP) response to CNP in rat carotid artery exposed to air-dry injury [13].

ANP-stimulated dilatation of isolated pulmonary arteries from chronically hypoxic rats may be increased but this is still controversial in previous pharmacological studies $[14,15]$. In addition, a recent study showed chronic hypoxia upregulates NP-B, but not NP-A receptor messenger ribonucleic acid (mRNA) expression, in the rat lung. To address this issue, the authors hypothesized that chronic hypoxia upregulates the pulmonary vasodilator responses to specific NPs in association with the functional change 
in NP receptor subtypes in rats. In this study, the authors investigated the vasodilator responses of isolated pulmonary vessels to NP family members (i.e., ANP, CNP, and ADM). These responses were compared with mRNA levels of NP-A and NP-B receptors in pulmonary vessels from hypoxic rats, as measured by ribonuclease (RNase) protection assay. Changes in the pathway downstream from cGMP were examined by measuring the responses to 8-bromoguanosine $3^{\prime}, 5^{\prime}$-cyclic monophosphate (8bromo-cGMP).

\section{Materials and methods}

\section{Pretreatment of animals}

Seven-week-old male Wistar rats (SLC, Sizuoka, Japan) weighing 160-210 g were randomly assigned to one of two groups: rats kept in a hypobaric hypoxic chamber (air at $50.5 \mathrm{kPa}(380 \mathrm{mmHg}))$ for 10 days $(\mathrm{n}=18)$; and control rats housed in ambient air at a normal atmospheric pressure $(n=23)$ for the pharmacological studies. In addition, rats exposed to hypobaric hypoxia for 10 days $(n=15)$ and control rats kept in the ambient air $(n=15)$ were made for the measurement of mRNA levels of NP-receptors. Because of the limitation of pulmonary artery (PA) tissue, 4-5 pulmonary vessels were collected and used as one sample for the RNase protection assay. Rats were kept and treated as reported previously [4, 16]. Briefly, rats were housed with 12-h light 12-h dark cycle and were fed standard rat chew and water ad libitum throughout the duration of hypobaric hypoxia. The pressure in the hypobaric chamber was reduced using an electrically driven vacuum pump. The chamber was open for $15 \mathrm{~min}$ once daily to allow cages to be cleaned and food and water to be replenished. All rats were weighed at the beginning of the treatment, 3, 6, and 10 days after the beginning of the treatment.

\section{Pulmonary vessel preparations}

Rats were anaesthetized with an intraperitoneal injection of pentobarbital $\left(50 \mathrm{mg} \cdot \mathrm{kg}^{-1}\right)$. The pulmonary vessels were prepared as reported previously [4]. Briefly, the lungs and heart were removed en bloc and placed in modified KrebsHenseleit solution at room temperature. The buffer composition was (in mM) $115.0 \mathrm{NaCl}, 4.7 \mathrm{KCl}, 2.5 \mathrm{CaCl}_{2}, 1.2$ $\mathrm{MgCl}_{2}, 25.0 \mathrm{NaHCO}_{3}, 1.2 \mathrm{KH}_{2} \mathrm{PO}_{4}$, and 10.0 dextrose. The right ventricle (RV) of the heart was dissected from the left ventricle plus septum $(\mathrm{LV}+\mathrm{S})$, and they were weighed separately. The ratios of $\mathrm{RV} /(\mathrm{LV}+\mathrm{S})$ and of $\mathrm{RV} /$ body weight $(\mathrm{BW})$ were calculated to determine whether right ventricular hypertrophy had developed. Two pulmonary arterial segments, a left extrapulmonary artery (EPA; 1.4$1.6 \mathrm{~mm}$ in external diameter) and an intrapulmonary artery (IPA; $0.7-1.1 \mathrm{~mm}$ in external diameter), were isolated and gently cleaned of fat and connective tissue. Ring segments ( $2 \mathrm{~mm}$ ) were cut (1-2 rings from EPA and 2-4 rings from IPA) and suspended vertically between hooks in organ baths $(5 \mathrm{~mL})$ containing modified Krebs-Henseleit solution, which was maintained at $37 \mathrm{C}$ and bubbled with a mixture of $95 \% \mathrm{O} 2$ and $5 \% \mathrm{CO}_{2}$. Optimal resting tension for vasodilator studies was $0.75 \mathrm{~g}$ for EPA, and $0.5 \mathrm{~g}$ for IPA in control animals, while the respective values were 1.0 and $0.75 \mathrm{~g}$ in hypoxic animals, as previously reported $[4,17]$. At these resting tensions, the peak contraction was obtained in response to $70 \mathrm{mM} \mathrm{KCl}$. In all experiments, the changes in isometric force were measured with a forcedisplacement transducer (TB 612; Nihon Kohden, Tokyo, Japan) connected to a carrier amplifier (AP600G; Nihon Kohden) and were recorded on a pen recorder (MC 6622; Watanabe, Tokyo, Japan).

\section{Vasodilator studies}

Vasodilator studies were performed as reported previously $[4,17]$. Briefly, arterial rings under the optimal resting tension were washed every $15-20 \mathrm{~min}$ and allowed to equilibrate for $80 \mathrm{~min}$. After the equilibration period, contraction curves for $70 \mathrm{mM} \mathrm{KCl}$ were routinely recorded twice with 50 min-interval for equilibration while washed three times. The peak contraction obtained from the second curve was taken as the maximal response to 70 $\mathrm{mM} \mathrm{KCl}$. A cumulative concentration-response curve for prostaglandin $\mathrm{F}_{2 \alpha}\left(\mathrm{PGF}_{2 \alpha}, 10^{-8}-10^{-5} \mathrm{M}\right)$ (Ono Pharmaceutical Inc., Osaka, Japan) was obtained and its maximal contraction was determined. Then the pulmonary arterial rings were washed every $15-20 \mathrm{~min}$, equilibrated for 50 min, and precontracted with $\mathrm{PGF}_{2 \alpha}\left(10^{-6}-10^{-5} \mathrm{M}\right.$ based on the $\mathrm{PGF}_{2 \alpha}$ concentration-response curve) to obtain $50-70 \%$ of the maximal concentration induced by $70 \mathrm{mM}$ $\mathrm{KCl}$. In the first study, after precontraction with $\mathrm{PGF}_{2 \alpha}$, a cumulative concentration-response curve was obtained for CNP-22 $\left(10^{-9}-10^{-6.5} \mathrm{M}\right)$ (Peninsula Laboratories, Belmont, CA, USA) by stepwise increases in the drug concentrations as the responses reached a plateau. At the end of the study, papaverine $\left(10^{-4} \mathrm{M}\right)$ (Nacalai Tesque Inc., Kyoto, Japan) was administered to produce the maximal relaxation. The magnitude of papaverine-induced relaxation was taken as $100 \%$ and the relaxing response to the particular vasodilator at each concentration was expressed as the percentage of this relaxation [4, 17]. After the equilibration period of $50 \mathrm{~min}$ while washed three times, a dose-response curve for rat ANP $\left(10^{-9}-10^{-7} \mathrm{M}\right)$ (Peninsula Laboratories) was also obtained in the vessels precontracted with $\mathrm{PGF}_{2 \alpha}$, and papaverine $\left(10^{-4} \mathrm{M}\right)$ was similarly administered at the end of the study. In the second study, to investigate whether the endotheliumdependent or -independent relaxation to rat ADM (Phoenix Pharmaceuticals, Inc., Mountain View, CA, USA) were impaired, the concentration-response curve for ADM $\left(10^{-10}-10^{-7} \mathrm{M}\right)$ was obtained in the vessels precontracted with $\mathrm{PGF}_{2 \alpha}$, in the presence or absence of $10^{-4} \mathrm{M} N^{\omega}$ nitro-L-arginine methyl ester (L-NAME) (Sigma, Tokyo, Japan), a nitric oxide synthase inhibitor. In the third study, the response to 8 bromo-cGMP $\left(10^{-6}-10^{-3.5} \mathrm{M}\right)$ was examined similarly. The potencies of $\mathrm{PGF}_{2 \alpha}$ and vasodilators were expressed as the negative log EC50 where the EC50 was the drug concentration producing $50 \%$ of the maximal responses to the particular agent.

\section{Ribonucleic acid extraction}

Rats were anaesthetized by the intraperitoneal injection of pentobarbital $\left(50 \mathrm{mg} \cdot \mathrm{kg}\right.$ body weight $\left.{ }^{-1}\right)$. The left and right extrapulmonary arteries were quickly excised, frozen in liquid nitrogen, and stored at $-80^{\circ} \mathrm{C}$. The heart was also excised for the evaluation of right ventricular hypertrophy. Total ribonucleic acid (RNA) extracts from the tissue were 
obtained by the acid guanidinium-thiochanate-phenol-chloroform method using a Teflon homogenizer (model THF; Takashima, Tokyo, Japan), as reported previously [1821].

Preparation of complementary ribonucleic acid probe and sense ribonucleic acid standard

The complementary(c) deoxyribonucleic acid (DNA) fragments corresponding to rat NP-A, NP-B receptors, and glyceraldehyde-3-phosphate dehydrogenase (GAPDH) were obtained from rat adrenal tissue by reverse transcriptionpolymerase chain reaction (RT-PCR) as described in detail previously [18-21]. Then the BsrI-EcoRI fragment of the PCR product of the NP-A receptor (175 base pairs (bp)), the PstI-NcoI fragment of the PCR product of the NP-B receptor (246 bp), and the PCR product of the GAPDH $(110 \mathrm{bp})$ were subcloned into multicloning sites between the T3 and T7 promoters of plasmid Bluescript II SK (Stratagene, La Jolla, CA, USA). After sequencing the PCR products, the purified plasmids were linearized by restriction enzymes (Boehringer Mannheim, Mannheim, Germany), as described in detail previously [18-21]. Respective antisense cRNA probes were synthesized in the presence of T3 RNA polymerase (Stratagene) for the NP-A receptor or T7 RNA polymerase (Stratagene) for the NP-B receptor and GAPDH, respectively, with 3.7 $\mathrm{MBq}^{32} \mathrm{P}$-uridine triphosphate (UTP) $\left(30 \mathrm{TBq} \cdot \mathrm{mmol}^{-1}\right.$ ), and the other three unlabelled nucleotides using RNA transcription kits (Stratagene). To generate the sense RNA standard of each NP receptor, the unlabelled sense strand NP receptor RNA was synthesized using the opposite side of the promoter from each linearized vector as template.

\section{Ribonuclease protection assay}

The RNase protection assay for quantitative analysis of the mRNA level was performed according to the methods described previously [18-21]. Briefly, $20 \mu \mathrm{g}$ sample RNA or synthesized sense RNA standard were hybridized with $1 \times 10^{5}(\mathrm{cpm}){ }^{32} \mathrm{P}$-UTP-labelled NP-A or NP-B receptor probe in $30 \mu \mathrm{L} 40 \mathrm{mM}$ piperazine- $N, N$-bis-(2-ethanesulphonic acid) (Nakalai Tesque Co., Kyoto, Japan), $\mathrm{pH}$ 6.4, containing $80 \%$ formamide, $0.4 \mathrm{M} \mathrm{NaCl}$, and 1 $\mathrm{mM}$ ethylene diamine tetra-acetic acid (EDTA). For RNA hybridization of the sample, $1 \times 10^{5} \mathrm{cpm}$ GAPDH probe was also added to the hybridization mixture. The mixture was heated at $85^{\circ} \mathrm{C}$ for $8 \mathrm{~min}$ and incubated at $55^{\circ} \mathrm{C}$ for
12 h. Nonannealing nucleic acids were digested with RNase-A (Boehringer Mannheim) and T1 (Sigma) at final concentrations of 40 and $2 \mu \mathrm{g} \cdot \mathrm{mL}^{-1}$, respectively, in $10 \mathrm{mM}$ tris-hydroxymethyl-amino methane (Tris)-HCL buffer, $\mathrm{pH} 8.0$, containing $300 \mathrm{mM} \mathrm{NaCl}$ and $5 \mathrm{mM}$ EDTA at $37^{\circ} \mathrm{C}$ for $40 \mathrm{~min}$. The protected fragments were electrophoresed on $5 \%$ polyacrylamide gel containing $7 \mathrm{M}$ urea (urea-polyacrylamide gel electrophoresis (PAGE)). Then, the dried gels were exposed to radiographic films (Kodak XAR-5; Eastman Kodak, Rochester, NY, USA) between two intensifying screens for $24 \mathrm{~h}$ for NP-A receptor, and 48 $h$ for the NP-B receptor. To quantitate signals of GAPDH transcripts, the gels were re-exposed to the films for $12 \mathrm{~h}$. The integrated optical density of the radioactive bands was determined densitometrically with a computing densitometer (model ACD-25DX; ATTO, Tokyo, Japan) and normalized by that of GAPDH in each sample. Each NP receptor mRNA level in the sample was quantified from the standard curve obtained with known amounts of synthesized sense RNA and expressed in amol mRNA $10 \mu \mathrm{g}$ total RNA $^{-1}$.

\section{Statistical analysis}

Results were expressed as mean \pm SEM. Differences between control and experimental animals were determined by the unpaired t-test. When more than two groups were compared, a one-way analysis of variance (ANOVA) was used, followed by the Scheffé F-test. A p-value of $<0.05$ was accepted as statistically significant.

\section{Results}

Body weight gain and right ventricular hypertrophy in hypobaric hypoxia

The initial body weight was similar in the control and hypoxic animals. The hypoxic rats lost weight during the first 6 days of hypoxic exposure, but regained some of it afterward. The rats kept in ambient air, in contrast, gained weight steadily. On the final day of this treatment, the hypoxic rats had significantly lower body weights than the control rats $(\mathrm{p}<0.05$; table 1$)$. Chronic hypobaric exposure induced significant right ventricular hypertrophy, as evaluated by $\mathrm{RV} /(\mathrm{LV}+\mathrm{S})$ and $\mathrm{RV} / \mathrm{BW}(\mathrm{p}<0.05$; table 1$)$, compared with ambient animals $[4,16]$.

Table 1. - Effects of exposing rats to chronic hypoxia

\begin{tabular}{|c|c|c|c|c|c|c|c|c|c|c|}
\hline & \multicolumn{2}{|c|}{$\begin{array}{c}\text { Body weight } \\
\mathrm{g}\end{array}$} & \multicolumn{2}{|c|}{$\begin{array}{l}\mathrm{RVH} \\
\mathrm{mg} \cdot \mathrm{g}^{-1}\end{array}$} & \multicolumn{2}{|c|}{$\begin{array}{c}\text { Contraction } \\
\text { by } 70 \mathrm{mM} \mathrm{KCl} \mathrm{mg} \\
\end{array}$} & \multicolumn{2}{|c|}{$\begin{array}{l}\text { Maximal contraction } \\
\text { by } \mathrm{PGF}_{2 \alpha}, \mathrm{mg}\end{array}$} & \multicolumn{2}{|c|}{$\begin{array}{l}\log \mathrm{EC}_{50} \\
\text { of } \mathrm{PGF}_{2 \alpha}\end{array}$} \\
\hline & Initial & Final & RV/(LV+S) & $\mathrm{RV} / \mathrm{BW}$ & IPA & EPA & IPA & EPA & IPA & EPA \\
\hline Control & $180 \pm 2$ & $227 \pm 2$ & $0.22 \pm 0.00$ & $0.39 \pm 0.01$ & $255 \pm 9$ & $355 \pm 20$ & $158 \pm 8$ & $253 \pm 14$ & $5.5 \pm 0.0$ & $5.6 \pm 0.1$ \\
\hline Subject $\mathrm{n}$ & 23 & 23 & 17 & 17 & 67 & 67 & 17 & 17 & 67 & 17 \\
\hline Нypoxia & $187 \pm 3$ & $175 \pm 2 *$ & $0.38 \pm 0.01 *$ & $0.71 \pm 0.02 *$ & $280 \pm 13$ & $369 \pm 29$ & $201 \pm 11 *$ & $330 \pm 27 *$ & $5.6 \pm 0.0^{*}$ & $5.7 \pm 0.1$ \\
\hline Subjects $n$ & 18 & 18 & 14 & 14 & 56 & 14 & 67 & 17 & 67 & 17 \\
\hline
\end{tabular}

Data are presented as mean \pm SEM or absolute numbers. RVH: right ventricular hypertrophy; RV: right ventricle; LV: left ventricle; S: ventricular septum; BW: body weight; IPA: intrapulmonary artery; EPA: extrapulmonary artery; PGF $_{2 \alpha}$ : prostaglandin $\mathrm{F}_{2 \alpha}$; EC50: the concentration producing $50 \%$ of the maximal response to $\mathrm{PGF}_{2 \alpha}{ }^{*}: \mathrm{p}<0.05$ versus contol. 
Responses to 70 millimolar potassium chloride and prostaglandin $F 2 \alpha$

Extra- or intrapulmonary arterial rings from control and hypoxic rats showed similar contraction in response to 70 $\mathrm{mM} \mathrm{KCl}$, while the maximal contraction of these rings in response to $\mathrm{PGF}_{2 \alpha}$ was significantly greater in hypoxic animals than in control animals $(\mathrm{p}<0.05$; table 1$)$. The negative $\log \mathrm{EC} 50$ of $\mathrm{PGF}_{2 \alpha}$ in EPA was similar in control and hypoxic animals, while in IPA, it was slightly higher in hypoxic animals than in control animals, $(p<0.05)$.

\section{Responses to vasodilators}

In both EPA and IPA from hypoxic rats, the relaxation induced by ANP $\left(10^{-8}-10^{-7} \mathrm{M}\right.$ in EPA and $10^{-8,5}-10^{-7} \mathrm{M}$ in IPA) was significantly greater than in control rats $(\mathrm{p}<0.05$, fig. 1). Although the maximal relaxation induced by ANP was greater in EPA and IPA of hypoxic rats than in control animals $(p<0.05)$, the negative log EC50 in each vessel of hypoxic animals was comparable to that in control (table 2). The relaxation responses of EPA and
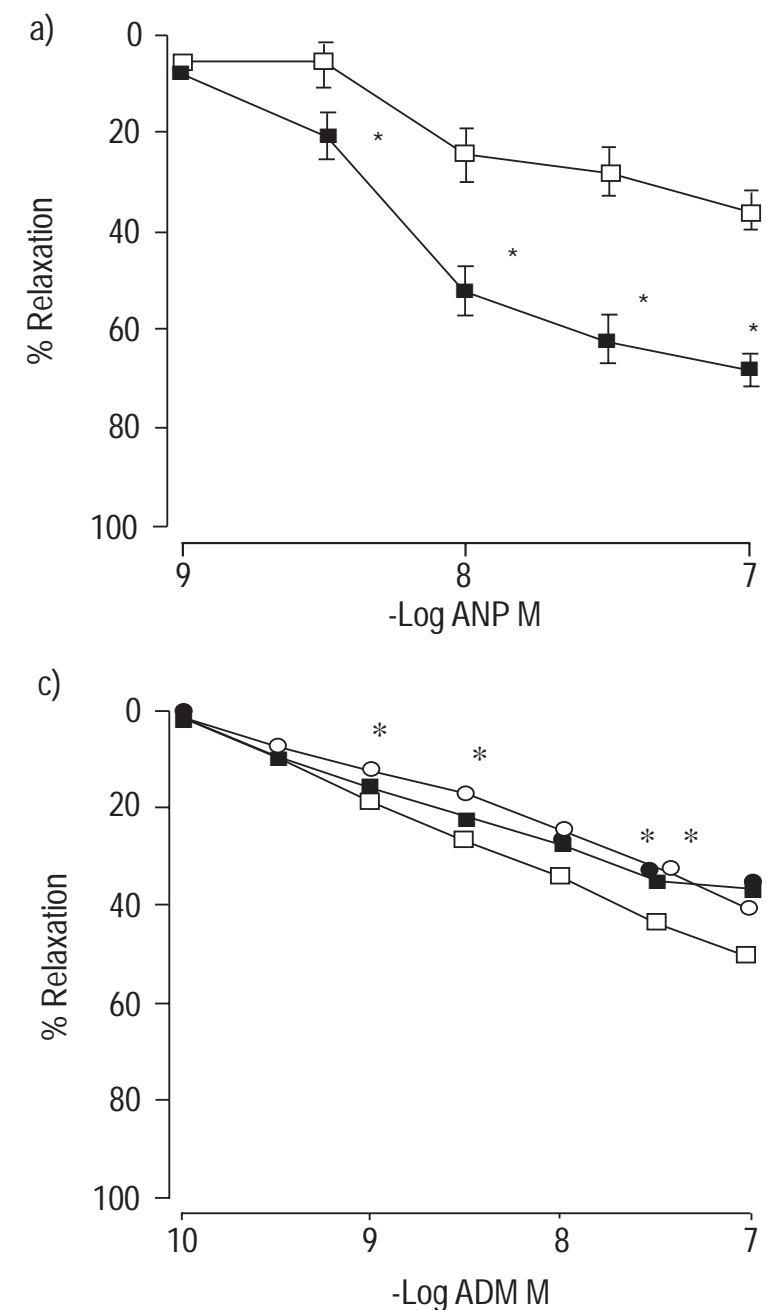

IPA to CNP were similar between hypoxic and control animals, with a comparable negative log EC50 and maximal relaxation (fig. 1; table 2 ). In the absence of L-NAME $10^{-4}$ $\mathrm{M}$, the relaxations of IPA by ADM $\left(10^{-9,}-8.5,-7,5,-7 \mathrm{M}\right)$ was impaired in hypoxic animals with no change of the negative $\log$ EC50, whereas in the presence of L-NAME $10^{-4} \mathrm{M}$, relaxations by ADM at every tested concentrations were similar between control and hypoxic animals (fig. 1; table 2). The impaired responses (in the absence of L-NAME $10^{-4} \mathrm{M}$ ) in hypoxic animals were comparable to the responses in hypoxic and control animals in the presence of L-NAME $10^{-4} \mathrm{M}$. The relaxation responses of IPA to 8-bromo-cGMP were similar between control and hypoxic animals, except at an unphysiological concentration $\left(10^{-3.5}\right)$ of the drug. (fig. 1 ; table 2$)$.

\section{Messenger ribonucleic acid levels of natriuretic peptide and $-B$ receptors}

Each protected band of NP-A and NP-B receptor mRNA in the whole lungs and extrapulmonary arteries showed a single band at the expected size on urea-PAGE.

b)

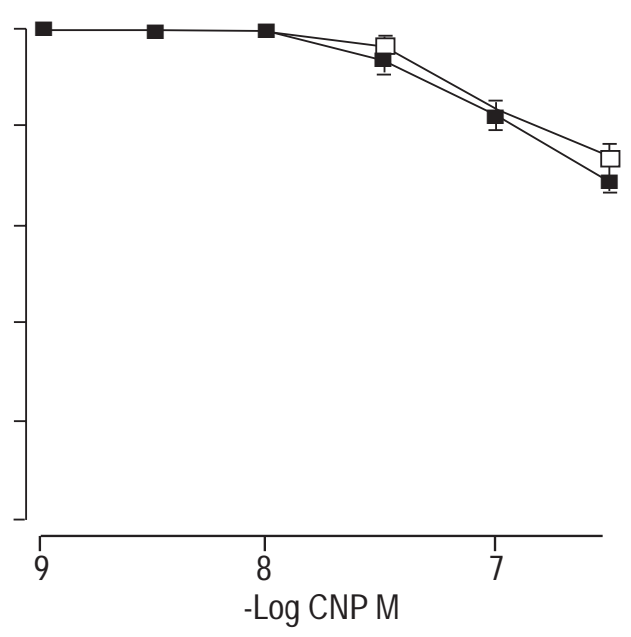

d)

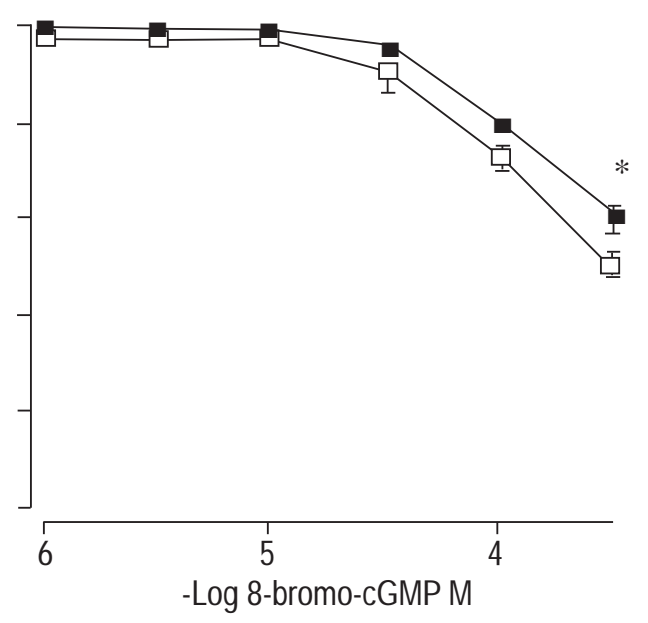

Fig. 1. - Relaxation elicited by natriuretic peptides and 8-bromoguanosine $3^{\prime}, 5^{\prime}$ - cyclic monophosphate (8-bromo-cGMP) in rat intrapulmonary vessels. Control $(\square)$ and hypoxic rats ( $\square$ ) without $N^{\omega}$-nitro-L-arginine methyl ester (L-NAME), and in c) control (O) and hypoxic rats $(\bigcirc)$ with L-NAME $10^{-4}$ M. The data points represent mean \pm SEM. a) atrial natriuretic peptide (ANP), b) C-type natriuretic peptide (CNP), c) adrenomedullin (AM), d) 8-bromocGMP. The number of preparations were as follows: a) $\square: 7 ; \square: 10 ; \mathrm{b}) \square: 14 ; \square: 11 ; \mathrm{c}) \square: 16 ; \square: 20 ; \bigcirc: 13 ; \mathbf{\square}: 6 ; \mathrm{d}) \square: 12 ; \square: 11$. $\square:$ p $\square 0.05$ versus control rats without L-NAME. 
Table 2. - Responses to natriuretic peptides and 8-bromoguanosine 3',5'-cyclic monophosphate (8-bromo-cGMP)

\begin{tabular}{|c|c|c|c|c|c|c|c|c|c|c|c|c|c|c|}
\hline & \multicolumn{10}{|c|}{ IPA } & \multicolumn{4}{|c|}{ EPA } \\
\hline & \multicolumn{2}{|c|}{ ANP } & \multicolumn{2}{|c|}{ CNP } & \multicolumn{2}{|c|}{ ADM } & \multicolumn{2}{|c|}{$\begin{array}{c}\text { ADM (L-NAME) } \\
10^{-4} \mathrm{M}\end{array}$} & \multicolumn{2}{|c|}{ 8-bromo-cGMP } & \multicolumn{2}{|c|}{ ANP } & \multicolumn{2}{|c|}{$\mathrm{CNP}$} \\
\hline & $\begin{array}{c}\text { M.R. } \\
\%\end{array}$ & $\begin{array}{l}-\log \\
\text { EC50 }\end{array}$ & $\underset{\%}{\text { M.R. }}$ & $\begin{array}{l}-\log \\
\text { EC50 }\end{array}$ & $\begin{array}{c}\text { M.R. } \\
\%\end{array}$ & $\begin{array}{l}-\log \\
\text { EC50 }\end{array}$ & $\begin{array}{c}\text { M.R. } \\
\%\end{array}$ & $\begin{array}{l}-\log \\
\text { EC50 }\end{array}$ & $\begin{array}{c}\text { M.R. } \\
\%\end{array}$ & $\begin{array}{l}-\log \\
\text { EC50 }\end{array}$ & $\begin{array}{c}\text { M.R. } \\
\%\end{array}$ & $\begin{array}{l}-\log \\
\text { EC50 }\end{array}$ & $\underset{\%}{\text { M.R. }}$ & $\begin{array}{l}-\log \\
\text { EC50 }\end{array}$ \\
\hline & 39.0 & 8.25 & 25.9 & 7.18 & 50.1 & 8.55 & 40.6 & 8.22 & 49.2 & 4.08 & 44.7 & 8.48 & 24.3 & 7.35 \\
\hline Control & \pm 3.4 & \pm 0.13 & \pm 2.9 & \pm 0.05 & \pm 2.1 & \pm 0.09 & $\pm 2.8^{*}$ & \pm 0.09 & \pm 3.3 & \pm 0.07 & \pm 3.7 & \pm 0.15 & \pm 4.7 & \pm 0.09 \\
\hline \multirow[t]{2}{*}{ Subjects $n$} & 11 & & 18 & & 16 & & 13 & & 12 & & 8 & & 9 & \\
\hline & 69.8 & 8.24 & 31.0 & 7.13 & 36.9 & 8.82 & 35.2 & 8.88 & 39.4 & 4.03 & 77.6 & 8.36 & 35.2 & 7.17 \\
\hline Нypoxia & $\pm 3.5^{*}$ & \pm 0.07 & \pm 2.5 & \pm 0.09 & $\pm 1.7^{*}$ & \pm 0.08 & $\pm 3.1^{*}$ & \pm 0.07 & $\pm 3.1^{*}$ & \pm 0.04 & $\pm 4.2^{*}$ & \pm 0.13 & \pm 6.4 & \pm 0.11 \\
\hline Subjects $n$ & 10 & & 11 & & 20 & & 6 & & 11 & & 7 & & 8 & \\
\hline
\end{tabular}

Data are presented as mean \pm SEM or absolate numbers. IPA: intrapulmonary artery; ANP: atrial natriuretic peptide; CNP: C-type natriuretic peptide; ADM: adrenomedullin; L-NAME: $N^{\omega}$-nitro-arginine methyl ester; M.R., maximal relaxation; EC50: drug concentration required to produce $50 \%$ of maximal relaxation to a particular agents. *: p $<0.05$ versus control in the absence of L-NAME.

The NP-A receptor mRNA level in the whole lungs of hypoxic rats was similar to that in control rats, whereas the NP-B receptor mRNA level in the hypoxic animals was 2.0 -fold higher than in control animals ( $\mathrm{p}<0.01$; fig. 2). In contrast, both NP-A and NP-B receptor mRNA levels in extrapulmonary vessels were similar between hypoxic and control animals.

\section{Discussion}

The major finding in the present study is that chronic hypoxia augmented the direct pulmonary vasodilator response to ANP but not to CNP in rats, suggesting that, among NPs, the vasodilator response to ANP was selectively upregulated. The response to 8-bromo-cGMP was unchanged, while mRNA levels of NP-A and NP-B receptors were unchanged in isolated pulmonary vessels from hypoxic rats, suggesting that the ANP response may be enhanced via a post-transcriptional modulation of NP-A receptor. In contrast, vasorelaxation to ADM was slightly but significantly impaired in hypoxic animals, although this change was abolished by the pretreatment with L-NAME $10^{-4} \mathrm{M}$. These findings suggest that ADM-cAMP pathway may be preserved, although NO-mediated pulmonary vasodilation is impaired.

In chronically hypoxic rats, compared with control rats, exogenous ANP produces a greater pulmonary vasodilation in isolated, buffer-perfused lungs and in vivo models $[22,23]$, while endogenous plasma ANP level is elevated $[7,24]$. However, whether this enhanced response to exogenous ANP is associated with the upregulation of the direct ANP response of pulmonary arteries in chronically hypoxic rats has not been determined. Specifically, the manner in which chronic hypoxia modulates the direct vasorelaxing effects of ANP on the isolated pulmonary vessels in rats is still controversial. ANP-stimulated dilatation of isolated pulmonary arteries from chronically hypoxic rats is increased in the study by RogERs et al. [15] but not in that of HiLL et al. [14]. The present study showed that chronic hypoxia selectively augmented the vasodilator response of the hypertensive pulmonary vessels to ANP in rats. This finding is consistent with the finding of Rogers et al. [15], but not with HiLl et al. [14]. The conflicting results may be related to the strain difference
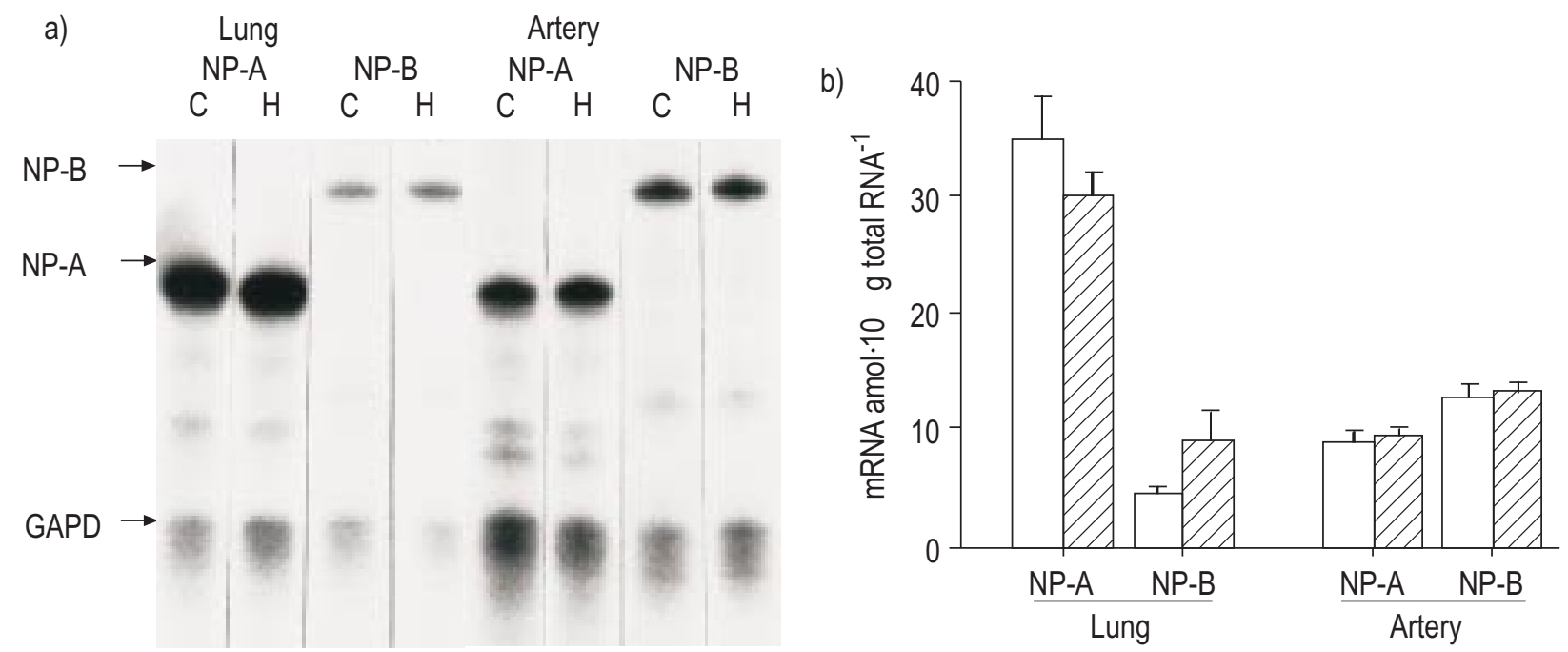

Fig. 2. - Natriuretic peptide (NP)-A (175 base pairs (bp)) and NP-B (251 bp) receptor messenger (m) ribonucleic acid (RNA) levels in rat extrapulmonary arteries and whole lungs. a) Autoradiogram following polyacrylamide gel electrophoresis. b) The mRNA levels of each NP receptor ( $\square$ : control $(\mathrm{C})$; $\mathscr{Z}$ : hypoxic rats $(\mathrm{H})$ ). Data are expressed as mean \pm SEM (lung mRNA, C: $\mathrm{n}=4, \mathrm{H}: \mathrm{n}=3$; artery mRNA, C: $\mathrm{n}=3$, H: $\mathrm{n}=4$ ). GAPD: glyceraldehyde-3-phosphate dehydrogenase (110 bp). *: $\mathrm{p}<0.01$ versus control. 
that can affect pulmonary vasorelaxing activity: RoGERS et al. [15] used Wistar rats, whereas HiLl et al. [14] used Sprague-Dawley rats. However, the former study [15] was equivocal with respect to the specificity of the effects, because they did not evaluate responses to other drugs. Their findings suggested that the enhanced responses of ANP could be nonspecific, representing the greater intrinsic tone in the experimental vessels using the similar methods, as in their study in monocrotaline-treated rats [25]. The current authors' present and previous studies [4] confirmed the specificity of the ANP response; vasorelaxing responses to NO, SNP and isoproterenol were severely impaired in hypoxic rats, while the response to an adenylate cyclase stimulator, forskolin, was preserved. Thus, the present observation suggests that chronic hypoxia specifically enhances ANP-elicited relaxation of isolated rat pulmonary arteries.

Chronic hypoxia modulates the gene expression of NP receptors in rat lungs. Recent studies by KLINGER et al. [26] Li et al. [27], using Northern blot and binding kinetics analysis of ANP receptors, showed that the ANP-clearance receptor expression was downregulated, while only NP-B receptor expression was upregulated in lungs from chronically hypoxic rats, which the current authors confirmed was working in their animal models. These findings suggested that the downregulation of ANP-clearance receptor might account for increased vasorelaxant response to exogenous ANP in vivo and in isolated perfused lungs. However, mRNA expression of NP receptors in pulmonary arteries was not examined or compared with the vasorelaxant response in hypoxic rats. The current study showed that mRNA levels of NP-A and NP-B receptors in the isolated PA were unchanged in hypoxic rats. In addition, the pathway downstream from cGMP was preserved, as shown by the normal response to 8-bromocGMP. This is consistent with a previous finding that the ability of cGMP to activate G-kinase in hypoxic rats is comparable to that in control rats [28]. Thus the present findings, using a vascular strip study and RNase protection assay, suggest that ANP-elicited vasodilator response was augmented possibly via the post-transcriptional modulation of the receptor function in hypoxic rats. Taken together, these findings imply that upregulated NPA receptor function, as well as downregulation of ANPclearance receptor [26, 27], may account for increased vasorelaxant response to exogenous ANP in vivo and in isolated perfused lungs. Conversely, chronic hypoxia did not change CNP response or NP-B receptor expression in isolated rat pulmonary arteries These findings support the hypothesis that NP-A receptor function may be selectively upregulated in hypoxic rats.

The mechanism of selective upregulation of NP-A receptor function is poorly understood. However, this finding is interesting, because the vasorelaxing response of the pulmonary vessels to NPs might have a similar mechanism to the vasomotor function of aorta from the spontaneously hypertensive rats (SHR) [29] rather than to phenotypically-modulated neointimal smooth muscle cells observed after endothelial injury. In SHR, WEI et al. [29] showed that the relaxing response of the aorta to ANP was increased, whereas that to CNP was not. Although the mechanism of those responses in SHR was not addressed in the study by WeI et al. [29], the recent study by YosHIмото et al. [21] showed that treatment of the cultured aortic smooth muscle cell with angiotensin II augmented ANP-stimulated cGMP generation, while NP-A and NP$B$ receptor mRNA was unchanged. Since increased angiotensin II production contributes to the progression of hypoxic pulmonary hypertension [30], ANP-stimulated cGMP production in pulmonary arteries may be augmented via angiotensin II upregulation in chronically hypoxic rats. Alternatively, this discrepancy might be related to receptor stabilization or increased receptor recycling as in the case with the deoxycorticosterone acetate-salt hypertensive rats, in which higher NP-A activity was confirmed in the presence of a lower level of its mRNA in the kidney [31].

Vasorelaxation to ADM was slightly but significantly impaired in hypoxic animals, whereas the pretreatment with L-NAME $10^{-4} \mathrm{M}$ abolished the difference in vasodilator responses between control and hypoxic animals. However, the presence of L-NAME did not affect the responses of hypertensive vessels to ADM. These observations suggest that the relaxant activity of ADM in rat pulmonary vessels was partially mediated by endothelium-derived NO, which is consistent with the previous reports using hindquarters vascular bed in the rat [10]. These data suggested that impaired vasodilator responses to ADM in hypoxic rats were due to loss of endothelial production of NO or the diminished NO sensitivity of the smooth muscle, rather than to the decreased sensitivity of smooth muscle to ADM via cAMP, which is consistent with the responses to acetylcholine in hypoxic rats [4].

In summary, chronic hypoxia upregulated the direct atrial natriuretic peptide-elicited relaxation of isolated pulmonary arteries in rats. This exaggerated response may be due to a selectively enhanced function of natriuretic peptide-A receptor subtype via a post-transcriptional mechanism. This finding suggests that among the natriuretic peptide family, direct augmentation of the atrial natriuretic peptide-elicited response may contribute to counteracting the development of hypoxic pulmonary hypertension, which is also compensated by an increased production of atrial natriuretic peptide and the reduction in pulmonary clearance receptors [24, 26, 27]. Taken together, these pharmacological characteristics of atrial natriuretic peptide were consistent with the hypothesis that the atrial natriuretic peptide system is protective against the development of pulmonary hypertension.

\section{References}

1. Meyrick B, Reid L. Endothelial and subintimal changes in rat hilar pulmonary artery during recovery from hypoxia. Lab Invest 1980; 42: 603-615.

2. Rosenberg H, Rabinovitch M. Endothelial injury and vascular reactivity in monocrotaline pulmonary hypertension. Am J Physiol 1988; 255: H1484-H1491.

3. Altiere RJ, Olson JW, Gillespie MN. Altered pulmonary vascular smooth muscle responsiveness in monocrotalineinduced pulmonary hypertension. J Pharmacol Exp Ther 1986; 236: 390-395.

4. Maruyama J, Maruyama K. Impaired nitric oxide-dependent responses and their recovery in hypertensive pulmonary arteries of rats. Am J Physiol 1994; 266: H2476-H2488.

5. Rodman DM. Chronic hypoxia selectively augments rat pulmonary artery $\mathrm{Ca}^{2+}$ and $\mathrm{K}^{+}$channel-mediated relaxation. Am J Physiol 1992; 263: L88-L94. 
6. Wanstall JC, O'Donnell SR. Responses to vasodilator drugs on pulmonary artery preparations from pulmonary hypertensive rats. Br J Pharmacol 1992; 105: 152-158.

7. Maack T. Receptors of atrial natriuretic factor. Annu Rev Physiol 1992; 54: 11-27.

8. Suga S, Nakao K, Ito H, et al. Endothelial production of C-type natriuretic peptide and its marked augmentation by transforming growth factor- $\beta$. J Clin Invest 1992; 90 : $1145-1149$.

9. Suga S, Nakao K, Kishimoto I, et al. Receptor selectivity of natriuretic peptide family, atrial natriuretic peptide, brain natriuretic peptide, and C-type natriuretic peptide. Endocrinology 1992; 130: 229-239.

10. Feng CJ, Kanf B, Kaye AD, Kadowitz PJ, Nossaman BD. L-NAME modulates responses to adrenomedullin in the hindquarters vascular bed of the rat. Life Sci 1994; 55: PL433-PL438.

11. Kitamura K, Kangawa K, Kawamoto M. Adrenomedullin: a novel hypotensive peptide isolated from human pheochromocytoma. Biochem Biophys Res Commun 1993; 192: 553-560.

12. Suga S, Nakao K, Kishimoto I, et al. Phenotype-related alteration in expression of natriuretic peptide receptors in aortic smooth muscle cells. Circ Res 1992; 71: 34-39.

13. Furuya M, Aisaka K, Miyazaki T, et al. C-type natriuretic peptide inhibits intimal thickening after vascular injury. Biochem Biophys Res Commun 1993; 193: 248-253.

14. Hill HS, Klinger JR, Warburton RR, Pietras L, Wrenn DS Brain natriuretic peptide: possible role in the modulation of hypoxic pulmonary hypertension. Am J Physiol 1994; 266: L308-L315.

15. Rogers TK, Stewart AG, Morice AH. Effect of chronic hypoxia on rat pulmonary resistance vessels: vasodilation by atrial natriuretic peptide. Clin Sci 1992; 83: 723-729.

16. Mitani Y, Maruyama K, Sakurai M. Prolonged administration of L-arginine ameliorates chronic pulmonary hypertension and pulmonary vascular remodeling in rats. Circulation 1997; 96: 689-697.

17. Toda N, Hayashi S. Age-dependent alteration in response of isolated rabbit basilar arteries to vasoactive agents. $J$ Pharmacol Exp Ther 1979; 211: 716-721.

18. Yoshimoto T, Naruse M, Naruse $\mathrm{K}$, et al. Modulation of vascular natriuretic peptide receptor gene expression in hypertensive and obese hyperglycemic rats. Endocrinology 1995; 136: 2427-2434.

19. Yoshimoto T, Naruse M, Tanabe A, et al. Angiotensin converting enzyme inhibitor but not calcium blocker down-regulates gene expression of vascular natriuretic peptide receptor in hypertensive rats. Biochem Biophys Res Commun 1994; 205: 1595-1600.

20. Yoshimoto T, Naruse K, Shionoya K, et al. Angiotensin converting enzyme inhibitor normalizes vascular natriuretic peptide type A receptor gene expression via bradykinin-dependent mechanism in hypertensive rats. Biochem Biophys Res Commun 1996; 218: 50-53.

21. Yoshimoto T, Naruse M, Naruse K, et al. Angiotensin IIdependent down-regulation of vascular natriuretic peptide type $\mathrm{C}$ receptor gene expression in hypertensive rats. Endocrinology 1996; 137: 1102-1107.

22. Jin H, Yang RH, Thompson RM, Chen YF, Jackson R, Oparil S. Atrial natriuretic peptide lowers pulmonary artery pressure in hypoxia adapted rats. J Appl Physiol 1988; 65: 1729-1735.

23. Stewart AG, Thompson JS, Rogers TK, Morice AH. Atrial natriuretic peptide-induced relaxation of precontracted isolated rat perfused lungs: a comparison in control and hypoxia-adapted animals. Clin Sci 1992; 81: 201-208.

24. McKenzie JC, Tanaka CI, Inagami T, Misono KS, Klein RM. Alterations in atrial and plasma atrial natriuretic factor (ANF) content during development of hypoxia-induced pulmonary hypertension in the rat. Proc Soc Exp Biol Med 1986; 181: 459-463.

25. Wanstall JC, Thompson JS, Morice AH. Effects of atrial natriuretic peptide and nitroprusside on isolated pulmonary resistance and conduit arteries from rats with pulmonary hypertension. Br J Pharmacol 1993; 110: 1363-1368.

26. Klinger JR, Arnal F, Warburton RR, Ou LC, Hill NS. Downregulation of pulmonary atrial natriuretic peptide receptors in rats exposed to chronic hypoxia. $J$ Appl Physiol 1994; 77: 1309-1316.

27. Li H, Oparil S, Meng QC, Elton TS, Chen YF. Selective downregulation of ANP-clearance-receptor gene expression in lung of rats adapted to hypoxia. Am J Physiol 1995; 268: L328-L335.

28. Crawley DE, Zhao L, Giembycz MA, et al. Chronic hypoxia impairs soluble guanylyl cyclase-mediated pulmonary arterial relaxation in the rat. Am J Physiol 1992; 263: L325-L332.

29. Wei CM, Kim CH, Khraibi AA, Miller VM, Burnett JC. Atrial natriuretic peptide and $\mathrm{C}$-type natriuretic peptide in spontaneously hypertensive rats and their vasorelaxing actions in vitro. Hypertension 1994; 23: 903-907.

30. Morrell NW, Morris KG, Stenmark KR. Role of angiotensin-converting enzyme and angiotensin II in development of hypoxic pulmonary hypertension. Am J Physiol 1995; 269: H1186-H1194.

31. Nuglozeh E, Mbikay M, Stewart DJ, Legault L. Gene expression of natriuretic peptide receptors in rats with DOCA-salt hypertension. Am J Physiol 1997; 273: C1427-C1434. 